Article

\title{
The Interaction between Antioxidants Content and Allergenic Potency of Different Raspberry Cultivars
}

\author{
Ewelina Hallmann ${ }^{1, *} \mathbb{D}$, Alicja Ponder ${ }^{1}$, Mateusz Aninowski ${ }^{2}$, Tuya Narangerel ${ }^{2}$ \\ and Joanna Leszczyńska ${ }^{2}$ \\ 1 Institute of Human Nutrition Sciences, Department of Functional and Organic Food, \\ Warsaw University of Life Sciences, Nowoursynowska 159c, 02-776 Warsaw, Poland; alicja_ponder@sggw.pl \\ 2 Institute of Institute of Natural Resources and Cosmetics, Faculty of Biotechnology and Food Sciences, \\ Lodz University of Technology, Stefanowskiego 4/10, 90-924 Lodz, Poland; \\ mateusz.aninowski@edu.p.lodz.pl (M.A.); tuya.narangerel@dokt.p.lodz.pl (T.N.); \\ joanna.leszczynska@p.lodz.pl (J.L.) \\ * Correspondence: ewelina_hallmann@sggw.pl; Tel.: +48-22 5937036
}

Received: 20 February 2020; Accepted: 18 March 2020; Published: 20 March 2020

check for updates

\begin{abstract}
Food allergies are a very serious problem among consumers. The most common food allergies involve animal products, but they can also involve fruits such as berries. We aimed to determine whether organic farming is useful for the production of high-quality and safe fruits. Three varieties of raspberries 'Laszka', 'Glen Ample' and 'Polka' from organic and conventional production (neighboring farms) were collected over the two years of the experiment. Quantitative and qualitative analysis of phenolic compounds was carried out, and the content of Bet v1 and profilin was determined. The organic raspberries contained a lower level of phenolic compounds, especially anthocyanins. Conventional fruits were characterized by a higher allergenic potency than organic ones. We found a strong link between their anthocyanin content and the allergy status of conventional raspberry fruits. Therefore, organically produced raspberries are safer for consumers.
\end{abstract}

Keywords: allergenic potency; anthocyanins; flavonoids; organic; raspberry

\section{Introduction}

Raspberries are one of the most popular fruits in Europe. They are recognized by consumers as tasty and healthy fruits. Many studies have shown that regular fruit consumption can diminish the risk of many chronic diseases-such as neurodegenerative conditions, type 2 diabetes, some kinds of cancer, cardiovascular diseases, hypertension, overweight and obesity [1-5]—due to their biologically active compounds content. Plants in organic agriculture are cultivated without the use of artificial pesticides and mineral fertilizers. Only natural methods of plant protection and fertilization are allowed (Council Regulation (EC), 2007) [6]. Polyphenols are a large group of secondary metabolites produced by plants as a response to biotic and abiotic environmental stresses [7]. Organic raspberries contain significantly more bioactive compounds than conventionally raised berries [8]. The consumption of organic raspberries could, therefore, be more health promoting, due to the higher content of biologically active compounds in the fruits. On the other hand, it should be remembered that the consumption of raspberries carries the risk of food allergies. Reports on the allergenicity of small fruits (berries)—such as strawberries, raspberries, blackberries and blueberries-are still scarce, but they do exist [9]. During the last ten years, the prevalence of food allergies has increased up to $4 \%$ among adults and $6 \%$ among children. In berry fruits, a substantial proportion of the allergens have defense-related functions, and their expression is highly influenced by exposure to biotic and abiotic stress and diseases. Pathogenesis-related proteins (PRs) account for approximately $25 \%$ of plant food allergens, 
and some are responsible for extensive cross-reactions between plant-derived foods, pollen and latex allergens [10]. Bet $\mathrm{v} 1$ is the most frequent cause of pollen-related food allergies [11], which are the most frequent type of food allergy in adults. The clinical symptoms observed are elicited by Bet $\mathrm{v}$ 1-induced IgE, which can then cross-react with a number of Bet $\mathrm{v}$ 1-related proteins from plant-derived foods. In raspberry fruits, only two allergenic proteins, including different isoforms, have been identified and described. The Rub i 1 and Rub i 3 allergens in raspberry (Rubus idaeus L.) belong to the PR-10 group (17 kDa) and are homologous to the major birch pollen Bet v1 [12]. The biological function of these raspberry allergens is still unknown, and their protein sequence is highly variable within the same species [13]. A high degree of structural homology has been demonstrated between Fra a 1 (strawberry), Mal d 1 (apple) and Bet $\mathrm{v} 1$ from birch [14,15] and between PR-10 proteins from different Rosaceae fruits [16]. Rub i 1 and Rub i 3 are mainly responsible for the raspberry allergies occurring among berry fruit consumers. Profilins are the most widespread allergens throughout the plant kingdom. They are concentrated in the fruit cells' cytosol. The molecular mass of profilins is $12-15 \mathrm{kDa}$, and their molecular structure is highly conserved, with $70 \%-85 \%$ homology among different species [17]. Inhibition experiments with serum pools from patients with fruit allergies have demonstrated cross-reactivity among the profilins Pru a 4, Fra a 1, and Fra a 3 [18].

In the present study, we aimed to identify and determine the content of bioactive compounds such as anthocyanins and the analogues of the most common panallergen Bet $\mathrm{v} 1$ and the profilin content in different raspberry cultivars from organic and conventional cultivation. In the present literature, there is a complete lack of information about bioactive compound contents and the allergenic potential of raspberry cultivars. We investigated to see if there was a link between the flavonoid (anthocyanin) content in fruits and their allergenic status. The main hypothesis of the presented manuscript was to determine whether anthocyanin levels could be a determinant of the level of allergenic protein concentrations in raspberry fruit. If there is a relationship between anthocyanin concentration and potentially allergenic factors. Importantly, the present experiment was conducted over two years to be sure that the obtained results were not just a random effect.

\section{Materials and Methods}

\subsection{Origin of the Fruits}

The experiment was carried out in 2013-2014. Three raspberry cultivars were used for the experiment: 'Laszka', 'Glen Ample' and 'Polka'. The experiment was conducted on the products of private farms: two organic and two conventional. All data about the farms' locations and the methods used for farm management, the kind and dose of fertilizers used, and the methods used for plant protection at the time of cultivation are presented in Table 1. Detailed information on the weather forecast (minimum and maximum temperatures, number of hours of sunshine per day and rainfall) in the experimental area are presented in Figure 1.

\subsection{Plant Material Preparation}

For chemical analysis, the fruits of all cultivars from each of the experimental farms were harvested early in the morning and immediately transported (in cooling boxes) to the laboratory. A total of $250 \mathrm{~g}$ of fruits per sample were used in the analyses. All samples were freeze-dried using a Labconco (2.5) freeze-dryer (Warsaw, Poland, $-50{ }^{\circ} \mathrm{C}$, pressure $0.100 \mathrm{mBa}$ ). After the freeze-drying process, the plant material was ground in a laboratory mill A-11 (IKA ${ }^{\circledR}$, Königswinter, Germany). The ground samples were then stored at $-80^{\circ} \mathrm{C}$ to avoid bioactive compound losses.

\subsection{Polyphenols Separation and Identification}

Polyphenols were measured by HPLC using a previously described method [19]. In brief: 0.100 $\mathrm{mg}$ of freeze-dried raspberry powder was extracted with $5 \mathrm{~mL}$ of $80 \%$ methanol with HPLC purity. Samples were mixed on Vortex 326 M (Marki, Poland). Next, samples were put into sonic bath 
Polsonic-3 (Warsaw, Poland) with parameters: $10 \mathrm{~min}, 30^{\circ} \mathrm{C}, 5.5 \mathrm{kHz}$ ). After extraction samples were centrifuged $\left(10 \mathrm{~min}, 3780 \times g, 5^{\circ} \mathrm{C}\right)$. Obtained supernatant was collected to HPLC-vials and $100 \mu \mathrm{L}$ of extract was inject into Phenomenx Fusion 80-A (C-18) $4.6 \times 250 \mathrm{~mm}$ column (Warsaw, Poland). HPLC set: two pumps LC-20AD, controller CBM-20A, column oven SIL-20AC, spectrometer UV/Vis SPD-20 AV. Polyphenols were separated under gradient conditions with a flow rate of $1 \mathrm{~mL} / \mathrm{min}$. Two gradient phases were used: $10 \%(v: v)$ acetonitrile and ultrapure water (phase A) and 55\% (v:v) acetonitrile and ultrapure water (phase B). The phases were acidified by orthophosphoric acid ( $\mathrm{pH} 3.0$ ). The total time of the analysis was $38 \mathrm{~min}$. The phase-time program was as follows: $1.00-22.99 \mathrm{~min}, 95 \%$ phase A and $5 \%$ phase $B ; 23.00-27.99 \mathrm{~min}, 50 \%$ phase $A$ and $50 \%$ phase $B ; 28.00-28.99 \mathrm{~min}, 80 \%$ phase $A$ and $20 \%$ phase B; and $29.00-38.00 \mathrm{~min}, 95 \%$ phase $A$ and $5 \%$ phase $B$. The wavelengths were $250-370 \mathrm{~nm}$ for all polyhenolic compounds. Bioactive compounds were identified by using $99.9 \%$ pure standards (Sigma-Aldrich, Warsaw, Poland) and the retention times for the standards.
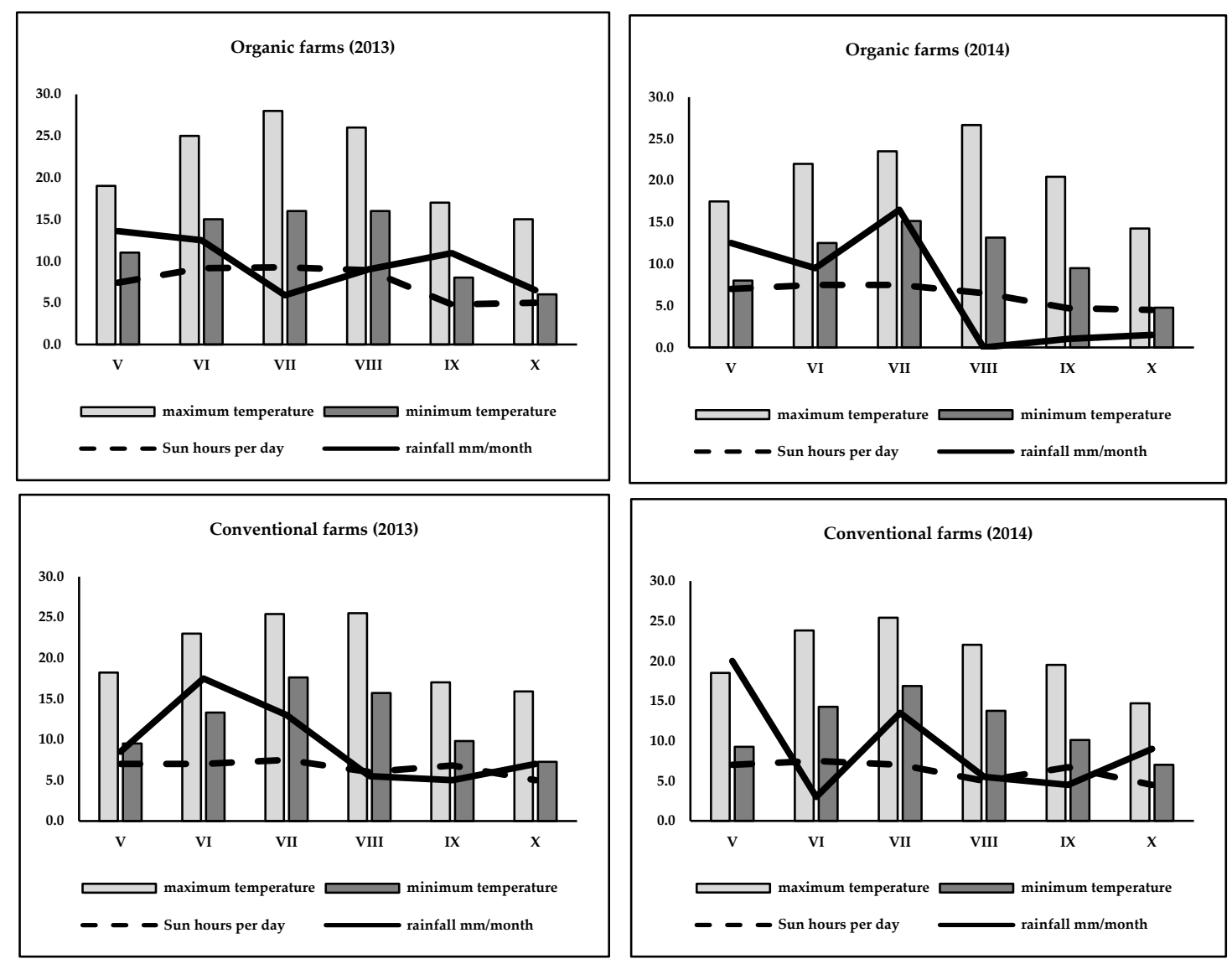

Figure 1. Weather conditions in experimental farms (organic and conventional) 2013-2014 in time of raspberry fruits development. 
Table 1. Characterization of localization, fertilizers regime and plant protection used for organic and conventional raspberry cultivation in (2013-2014).

\begin{tabular}{|c|c|c|c|c|c|}
\hline Cultivation System & Localization & Type of Soil & Kind of Fertilizer & Dose of Fertilizers and Time of Given & Plant Protection System \\
\hline \multirow{2}{*}{$\begin{array}{l}\text { Organic farm no. } 1 \\
\quad(n=6)\end{array}$} & Zakroczym & \multirow{2}{*}{$\begin{array}{l}\text { sandy middle soil IVa and IVb category }(15 \% \\
\text { floatable particles) } \mathrm{pH}(5.5), \mathrm{EC}(3.8)\end{array}$} & \multirow{2}{*}{ cow manure } & \multirow{2}{*}{35 t ha- 1 one year before raspberry planting } & \multirow{2}{*}{ Grevit 200 SL } \\
\hline & $\left(52^{\circ} 26^{\prime \prime} \mathrm{N} 20^{\circ} 36^{\prime \prime} \mathrm{E}\right)$ & & & & \\
\hline \multirow{2}{*}{$\begin{array}{l}\text { Organic farm no. } 2 \\
\qquad(n=6)\end{array}$} & Załuski & \multirow{2}{*}{$\begin{array}{l}\text { sandy middle soil, sandy-clay IV category } \\
\text { (20\% floatable particles), pH (5.5), EC (4.1) }\end{array}$} & \multirow{2}{*}{ cow manure } & \multirow[t]{2}{*}{30 tha- 1 one year before raspberry planting } & \multirow[t]{2}{*}{ no protection } \\
\hline & $\left(52^{\circ} 37^{\prime \prime} \mathrm{N} 20^{\circ} 22^{\prime \prime} \mathrm{E}\right)$ & & & & \\
\hline \multirow{2}{*}{$\begin{array}{l}\text { Conventional farm no. } 1 \\
\qquad(n=6)\end{array}$} & Czerwińsk nad Wisła & \multirow{2}{*}{$\begin{array}{l}\text { sandy-loamy middle soil IV and III category } \\
\text { (20\% floatable particles), pH (5.5), EC (5.2) }\end{array}$} & \multirow{2}{*}{$\begin{array}{l}\text { Hydrocomplex 12-11-18; } \\
\quad \text { Superba 8-11-36 }\end{array}$} & \multirow{2}{*}{$\begin{array}{l}(200 \mathrm{~kg} \text { ha- }-1,150 \mathrm{~kg} \text { ha- }-1) \text { in autumn a year before } \\
\text { raspberry planting; } 3 \text { doses in time of cultivation }\end{array}$} & \multirow{2}{*}{ Signum 33 WG, Miros $20 \mathrm{SP}$} \\
\hline & $\left(52^{\circ} 23^{\prime \prime} \mathrm{N} 20^{\circ} 20^{\prime \prime} \mathrm{E}\right)$ & & & & \\
\hline \multirow{2}{*}{$\begin{array}{l}\text { Conventional farm no. } 2 \\
\qquad(n=6)\end{array}$} & Czerwińsk nad Wisłą & \multirow{2}{*}{$\begin{array}{l}\text { sandy-loamy middle soil IV and III category } \\
\text { (25\% floatable particles), pH (5.5), EC (5.5) }\end{array}$} & \multirow{2}{*}{$\begin{array}{l}\text { amonium nitrate, polyphosphate, } \\
\text { magnesium sulphate }\end{array}$} & \multirow{2}{*}{$\begin{array}{c}\text { in autumn a year before raspberry planting; } \\
3 \text { doses in time of cultivation }\end{array}$} & \multirow{2}{*}{$\begin{array}{l}\text { Calypso } 480 \text { SC, Miros } 20 \mathrm{SP} \\
\text { Zato } 50 \text { WG }\end{array}$} \\
\hline & $\left(52^{\circ} 23^{\prime \prime} \mathrm{N} 20^{\circ} 20^{\prime \prime} \mathrm{E}\right)$ & & & & \\
\hline
\end{tabular}




\subsection{Anthocyanin Separation and Identification}

The first step of sample purification for the anthocyanin analysis was combined with the analysis of the polyphenols. The samples were extracted with $80 \%$ methanol. After the first centrifugation (see the previous section), $2.5 \mathrm{~mL}$ of supernatant was collected into a new plastic tube, and then $2.5 \mathrm{~mL}$ of $10 \mathrm{~mol}$ $\mathrm{HCl}$ and $5 \mathrm{~mL}$ of $100 \%$ methanol were added. The samples were gently shaken and put in a refrigerator $\left(5{ }^{\circ} \mathrm{C}, 10 \mathrm{~min}\right)$. Next, $1 \mathrm{~mL}$ of extract was transferred into HPLC vials and analyzed. The anthocyanins were separated under isocratic conditions with a flow rate of $1.5 \mathrm{~mL} / \mathrm{min}$. One mobile phase, $5 \%$ acetic acid, methanol and acetonitrile (70:10:20), was used. HPLC set was performed from modules: two pumps (LC-20AD), one controller (CBM-20A), column oven (SIL-20AC), one spectrometer (UV/Vis SPD-20 AV). Phenomenx Fusion 80-A $(4.6 \times 250 \mathrm{~mm}$, practical shape $4 \mu \mathrm{m})$ column $(\mathrm{C} 18)$ was used. The analysis time was $10 \mathrm{~min}$ at a wavelength of $570 \mathrm{~nm}$. The anthocyanins were identified by using $99.9 \%$ pure standards (Sigma-Aldrich) and the retention times for the standards [20].

\subsection{Allergenic Potential Analysis}

To obtain the proteins from the fruit, a Total Protein Extraction Kit for Plant Tissues (Sigma-Aldrich, Poland) was used. The analyses were performed according to the protocols described in a previous paper [19]. Their potential allergenicity was determined by indirect, non-competitive ELISA. For the primary antibodies, mouse antibodies against Bet v1 (Dendritics, Lion, France) for the detection of Bet v 1 analogues were used. Rabbit antibodies against profilin (Dendritics) for the determination of proteins such as profilin were also used. For the secondary antibodies, a conjugate of antibodies against mouse immunoglobulins with alkaline phosphatase (Sigma-Aldrich) or antibodies against the rabbit immunoglobulin conjugate with alkaline phosphate (Sigma-Aldrich) were used. The wells on the plates were blocked with a 3\% solution of commercial skim milk. As the substrate for alkaline phosphatase, pNPP ( $p$-Nitrophenyl Phosphate (pNPP, KR-pT-IRR, Ser/Thr Phosphatase Assay Kit, BioAssay ${ }^{\mathrm{TM}}$, Sigma-Aldrich) was used, $3 \mathrm{M} \mathrm{NaOH}$ (Sigma-Aldrich) was used as the stopping reagent, and as a washing agent, PBS with $0.1 \%$ Tween 20 (Sigma-Aldrich) were used. The absorbance was read at $405 \mathrm{~nm}$ with the use of a Multiscan RC microplate reader (Labsystems, Helsinki, Finland), and the results were calculated using a standard curve prepared with the Bet v 1 allergen or profilin.

\subsection{Statistical Analysis}

The results obtained from the chemical analyses were statistically analyzed using Statgraphics Centurion 15.2.11.0 software (StatPoint Technologies, Inc., Warranton, VA, USA). The values presented in the tables are expressed as the mean values for the organic and conventional cultivation systems for the three raspberry cultivars 'Laszka', 'Glen Ample' and 'Polka'. The statistical calculations were based on a two-way analysis of variance using Tukey's test $(p=0.05)$. A lack of statistically significant differences between the examined groups is indicated by labelling with the same letters. A standard error (SE) is given for each mean value reported in the tables. To obtain a better picture of the correlation between the identified biologically active compounds and the allergenic proteins, a Principle Component Analysis (PCA) was used. The PCA figures were made using XLStat Trial version (Microsoft Excel, Chicago, IL, USA). Another correlation was demonstrated by calculating Pearson's coefficients.

\section{Results}

The obtained results showed that the conventionally raised raspberries were characterized by a significantly $(p<0.0001)$ higher concentration of Bet v1 homologues than the organic ones, but only in 2013. In the next year of the experiment, we did not detect any difference between the raspberry fruits from the two cultivation systems regarding Bet v1. In 2014, the organic raspberries were characterized by $819.9 \mathrm{ng} / \mathrm{g}$ DW, and the conventional raspberries contained by $822.9 \mathrm{ng} / \mathrm{g}$ DW of Bet v1 homologues (Tables 2 and 3). It is interesting that in both years, 'Polka' cv. was characterized by the lowest concentration of Bet v1 among the examined raspberry cultivars. The reverse situation was observed for the profilins. 
In 2013, there were no differences between the organic and conventional raspberries, whereas in 2014, the conventional fruits contained significantly more $(p<0.0001)$ profilins.

In both years of the experiment, 'Laszka' cv. was characterized by a significant $(p<0.0001)$ level of profilins at $4.47 \mu \mathrm{g} / \mathrm{g}$ DW and $5.98 \mu \mathrm{g} / \mathrm{g}$ DW in 2013 and 2014, respectively. As shown in Tables 2 and 3, in both years, the conventional raspberries contained significantly more total polyphenols $(p=0.0004$ and $p<0.0001)$ than the organic ones. In 2013, the highest level of total polyphenols was found in 'Glen Ample' cv.; however, in 2014, it was the 'Polka' cv. fruits. The content of phenolic acids was dependent on the cultivation system and cultivar only in 2014. The conventional raspberries contained significantly more total phenolic acids, with a value of $416.0 \mathrm{mg} / 100 \mathrm{~g}$ DW. The highest concentration of total phenolic acid was observed in 2014 for 'Polka' cv. (496.8 mg/100 g DW). In 2013, we did not observe any effect of the farming system on the gallic acid content. Only in 2014 were the conventional raspberries characterized by significant $(p=0.0031)$ concentration of gallic acid

The examined cultivars had differences in their gallic acid content in the raspberry fruits. In 2013, the highest level of gallic acid was noticed in 'Polka' cv., but in 2014, the highest level was in 'Glen Ample' cv. (Tables 2 and 3). The content of chlorogenic acid was significantly higher in the conventional raspberry, though only in 2013. In both years of the experiment, 'Glen Ample' cv. was characterized by the highest level of chlorogenic acid in the fruits, with levels of $27.9 \mathrm{mg} / 100 \mathrm{~g}$ DW and 52.1 mg/100 g DW, respectively, in 2013 and 2014. The content of caffeic acid was quite variable between the experimental years. In 2013, the highest concentration of that compound was found in the organic raspberries, but in 2014, the concentration was higher in the conventionally raised raspberries. A similar situation was found for the effect of the cultivars. In 2013, in the 'Polka' cv. fruits, we found a significantly $(p<0.0001)$ higher concentration of caffeic acid, but in 2014 , the concentration was highest in the 'Laszka' cv. fruits $(p<0.000)$. In 2013, there were no differences in $p$-coumaric acid content between the organic and conventional raspberry fruits. In 2014, the organic raspberries contained significantly more $(8.14 \mathrm{mg} / 100 \mathrm{~g} \mathrm{DW}) p$-coumaric acid than the conventional ones (5.65 mg/100 g DW). The highest level of $p$-coumaric acid was found for 'Polka' cv. in 2013 and for 'Laszka' cv. in 2014 (Tables 2 and 3). The content of ferulic acid was only significantly higher in the conventional raspberry in 2013. We did not see any effect of the farming system or cultivar on the ferulic acid content in 2014 . In the case of ellagic acid, there were no differences in 2013; in 2014, the conventional raspberries contained significantly more $(p<0.0001)$ phenolic acid, and the 'Polka' cv. fruits contained significantly more $(p<0.0001)$ ellagic acid. In the case of total flavonoids, we observed that in both years of the experiment, the conventional raspberry contained significantly more $(p<0.0001)$ of these compounds than the organic ones. Only in 2013 did the cultivar 'Glen Ample' produce a significantly higher concentration of total flavonoids in the fruits $(819.5 \mathrm{mg} / 100 \mathrm{~g} \mathrm{DW})$. The organic raspberries contained significantly more total flavonols $(p=0.0027)$ but only in 2013. In the second year of the experiment, conventional raspberries were characterized by a higher concentration of total flavonols $(p<0.0001)$. In both years of the experiment, we observed that the conventional raspberry contained significantly more quercetin-3-O-rutinoside, with values of $8.83 \mathrm{mg} / 100 \mathrm{~g}$ DW and $14.10 \mathrm{mg} / 100 \mathrm{~g}$ DW, respectively, in 2013 and 2014. The cultivars had a significant effect on the quercetin derivative content. In 2013, the highest level of that compound was observed in 'Glen Ample' cv. fruits, but in 2014, the highest concentration was in 'Polka' cv. fruits (Tables 2 and 3). In both years of the experiment, the content of myricetin was significantly higher in the organic raspberries. Only in 2013 did we observe any effect of the cultivar on the myricetin content. Organic raspberries were characterized by a higher level of luteolin, but only in 2013. In the next year, we observed that conventional fruits contained significantly $(p<0.0001)$ more luteolin (Tables 2 and 3$)$. The content of quercetin-3-O-glucoside and kaempferol were significantly higher in the conventional raspberries only in 2014. The total anthocyanins and two of three individual compounds were significantly higher in conventional fruits in both years of the experiment. The effect of the cultivar was noticed only in 2013. 'Glen Ample' cv. fruits contained significantly more cyanidin and pelargonidin than the rest of the examined raspberry cultivars. The current experiment provides information about the impact of cultivation method (organic and conventional) on the quality of raspberries. The authors have applied a holistic "from farm to fork" approach. The presented experiment not only shows the nutritional value and the content of the bioactive compounds in different raspberry cultivars but also demonstrates how raspberries can affect consumers who suffer from allergy problems. The individual ELISA results are presented in Tables 4 and 5 
Table 2. The content of allergenic analogs and polyphenols in examined raspberry cultivars from organic and conventional farming system in 2013.

\begin{tabular}{|c|c|c|c|c|c|c|c|}
\hline \multirow{2}{*}{ Bioactive Compounds } & \multirow{2}{*}{$\begin{array}{c}\text { Organic } \\
\text { Raspberry }\end{array}$} & \multirow{2}{*}{$\begin{array}{c}\text { Conventional } \\
\text { Raspberry }\end{array}$} & \multirow{2}{*}{ ‘Laszka' cv. } & \multirow{2}{*}{ ‘Glen Ample' cv } & \multirow{2}{*}{ ‘Polka' cv. } & \multicolumn{2}{|c|}{$p$-Value } \\
\hline & & & & & & System & Cultivar \\
\hline Bet v1 $(\mu \mathrm{g} / \mathrm{g}$ DW $)$ & $786.40 \pm 27.00^{1} \mathrm{~B}^{2}$ & $864.69 \pm 52.15 \mathrm{~A}$ & $917.88 \pm 19.58 \mathrm{a}$ & $850.52 \pm 47.16 \mathrm{ab}$ & $708.24 \pm 27.07 \mathrm{~b}$ & $<0.0001$ & $<0.0001$ \\
\hline Profilins ( $\mu \mathrm{g} / \mathrm{g}$ DW) & $3.48 \pm 0.38 \mathrm{~A}$ & $3.49 \pm 0.34 \mathrm{~A}$ & $4.47 \pm 0.56 \mathrm{a}$ & $2.44 \pm 0.27 \mathrm{c}$ & $3.55 \pm 0.80 \mathrm{~b}$ & N.S. & $<0.0001$ \\
\hline Total polyphenols (mg/100 g DW) & $1009.84 \pm 0.55 \mathrm{~B}$ & $1172.36 \pm 0.35 \mathrm{~A}$ & $1029.83 \pm 0.10 \mathrm{~b}$ & $1172.41 \pm 0.08 \mathrm{a}$ & $1071.07 \pm 0.23 \mathrm{a}$ & 0.0004 & 0.0135 \\
\hline Total phenolic acids & $313.23 \pm 2.16 \mathrm{~A}$ & $359.33 \pm 4.41 \mathrm{~A}$ & $307.39 \pm 1.47 \mathrm{a}$ & $352.85 \pm 3.87 \mathrm{a}$ & $348.61 \pm 0.47 \mathrm{a}$ & N.S. & N.S. \\
\hline Gallic acid & $2.24 \pm 0.61 \mathrm{~A}$ & $2.46 \pm 0.63 \mathrm{~A}$ & $1.49 \pm 0.09 \mathrm{~b}$ & $1.80 \pm 0.39 \mathrm{~b}$ & $3.75 \pm 0.10 \mathrm{a}$ & N.S. & $<0.0001$ \\
\hline Chlorogenic acid & $14.97 \pm 3.39 \mathrm{~B}$ & $26.15 \pm 2.73 \mathrm{~A}$ & $13.56 \pm 0.43 \mathrm{~b}$ & $27.91 \pm 0.50 \mathrm{a}$ & $20.22 \pm 0.54 \mathrm{ab}$ & $<0.0001$ & $<0.0001$ \\
\hline Caffeic acid & $3.55 \pm 0.78 \mathrm{~A}$ & $2.27 \pm 0.49 \mathrm{~B}$ & $1.19 \pm 0.12 \mathrm{c}$ & $2.84 \pm 0.31 \mathrm{~b}$ & $4.70 \pm 0.15 \mathrm{a}$ & $<0.0001$ & $<0.0001$ \\
\hline$p$-Coumaric acid & $13.92 \pm 8.08 \mathrm{~A}$ & $13.43 \pm 8.24 \mathrm{~A}$ & $8.29 \pm 3.31 \mathrm{~b}$ & $8.65 \pm 3.86 b$ & $24.08 \pm 6.59 \mathrm{a}$ & N.S. & $<0.0001$ \\
\hline Ferulic acid & $5.23 \pm 1.35 \mathrm{~B}$ & $5.78 \pm 1.67 \mathrm{~A}$ & $4.10 \pm 1.39 \mathrm{~b}$ & $4.91 \pm 1.08 \mathrm{~b}$ & $7.49 \pm 1.36 \mathrm{a}$ & 0.0350 & $<0.0001$ \\
\hline Ellagic acid & $273.49 \pm 0.13 \mathrm{~A}$ & $307.86 \pm 0.57 \mathrm{~A}$ & $280.74 \pm 0.22 \mathrm{a}$ & $296.94 \pm 0.40 \mathrm{a}$ & $294.33 \pm 0.15 \mathrm{a}$ & N.S. & N.S. \\
\hline Total flavonoids (mg/100 g DW) & $696.61 \pm 2.54 \mathrm{~B}$ & $813.04 \pm 1.35 \mathrm{~A}$ & $722.45 \pm 3.04 \mathrm{~b}$ & $819.56 \pm 1.33 \mathrm{a}$ & $722.46 \pm 1.19 b$ & $<0.0001$ & 0.0002 \\
\hline Total flavonols (mg/100 g DW) & $55.42 \pm 2.68 \mathrm{~A}$ & $43.24 \pm 2.91 \mathrm{~B}$ & $45.13 \pm 2.34 \mathrm{~b}$ & $45.28 \pm 1.79 \mathrm{~b}$ & $57.57 \pm 1.96 \mathrm{a}$ & 0.0027 & 0.0050 \\
\hline Quercetin-3-O-rutinoside & $7.85 \pm 1.93 \mathrm{~B}$ & $8.83 \pm 2.21 \mathrm{~A}$ & $8.30 \pm 0.56 \mathrm{~b}$ & $9.09 \pm 0.55 \mathrm{a}$ & $7.63 \pm 0.43 c$ & 0.0016 & 0.0013 \\
\hline Myricetin & $26.60 \pm 0.68 \mathrm{~A}$ & $15.23 \pm 0.55 \mathrm{~B}$ & $23.73 \pm 0.08 \mathrm{a}$ & $17.31 \pm 0.31 \mathrm{~b}$ & $21.72 \pm 0.23 \mathrm{ab}$ & $<0.0001$ & 0.0080 \\
\hline Luteolin & $11.87 \pm 1.00 \mathrm{~A}$ & $8.93 \pm 1.17 \mathrm{~B}$ & $4.86 \pm 1.14 \mathrm{c}$ & $9.39 \pm 0.66 b$ & $16.96 \pm 0.23 \mathrm{a}$ & 0.0001 & $<0.0001$ \\
\hline Quercetin-3-O-glucoside & $4.37 \pm 0.87 \mathrm{~A}$ & $4.73 \pm 0.32 \mathrm{~A}$ & $2.87 \pm 0.68 \mathrm{c}$ & $4.75 \pm 0.56 \mathrm{~b}$ & $6.03 \pm 0.40 \mathrm{a}$ & N.S. & $<0.0001$ \\
\hline Kaempferol & $4.72 \pm 17.34 \mathrm{~A}$ & $5.51 \pm 1.68 \mathrm{~A}$ & $5.37 \pm 1.46 \mathrm{a}$ & $4.74 \pm 1.19 \mathrm{a}$ & $5.24 \pm 1.78 \mathrm{a}$ & N.S. & N.S. \\
\hline Total anthocyanins (mg/100 g DW) & $641.20 \pm 0.85 \mathrm{~B}$ & $769.80 \pm 10.42 \mathrm{~A}$ & $677.31 \pm 2.93 \mathrm{~b}$ & $774.28 \pm 11.74 \mathrm{a}$ & $664.89 \pm 5.47 \mathrm{~b}$ & $<0.0001$ & 0.0001 \\
\hline Cyanidin-3-O-glucoside & $320.21 \pm 17.34 \mathrm{~B}$ & $380.58 \pm 15.68 \mathrm{~A}$ & $344.49 \pm 3.46 \mathrm{ab}$ & $384.90 \pm 13.19 a$ & $321.79 \pm 16.78 b$ & 0.0006 & 0.0060 \\
\hline Pelargonidin-3-O-glucoside & $95.47 \pm 0.85 \mathrm{~B}$ & $141.44 \pm 10.42 \mathrm{~A}$ & $106.05 \pm 2.93 \mathrm{~b}$ & $135.16 \pm 11.74 \mathrm{a}$ & $114.16 \pm 5.47 \mathrm{ab}$ & $<0.0001$ & $<0.0001$ \\
\hline Delphinidinn-3-O-glucoside & $225.51 \pm 14.36 \mathrm{~A}$ & $247.78 \pm 15.36 \mathrm{~A}$ & $226.77 \pm 6.20 \mathrm{~b}$ & $254.22 \pm 8.38 \mathrm{a}$ & $228.94 \pm 14.66 \mathrm{~b}$ & N.S. & $<0.0001$ \\
\hline
\end{tabular}

1 Data are presented as the mean \pm SE with ANOVA $p$-value; ${ }^{2}$ Means in rows followed by the same letter (A, B, a-c) are not significantly different at the $5 \%$ level of probability $(p<0.05)$; N.S. not significant; (n) number of samples (field replications) $n=36$ for system, $n=12$ of cultivar. 
Table 3. The content of allergenic analogs and polyphenols in examined raspberry cultivars from organic and conventional farming system in 2014.

\begin{tabular}{|c|c|c|c|c|c|c|c|}
\hline \multirow{2}{*}{ Bioactive Compounds } & \multirow{2}{*}{ Organic Raspberry } & \multirow{2}{*}{$\begin{array}{l}\text { Conventional } \\
\text { Raspberry }\end{array}$} & \multirow{2}{*}{ ‘Laszka' cv. } & \multirow{2}{*}{ 'Glen Ample' cv. } & \multirow{2}{*}{ 'Polka' cv. } & \multicolumn{2}{|c|}{$p$-Value } \\
\hline & & & & & & System & Cultivar \\
\hline Bet v1 ( $\mu \mathrm{g} / \mathrm{g}$ DW) & $819.98 \pm 34.59^{1} \mathrm{~A}^{2}$ & $822.94 \pm 95.30 \mathrm{~A}$ & $804.42 \pm 22.45 \mathrm{~b}$ & $861.73 \pm 7.64 \mathrm{a}$ & $798.22 \pm 88.61 \mathrm{~b}$ & N.S. & 0.0002 \\
\hline Profilins $(\mu \mathrm{g} / \mathrm{g} D W)$ & $3.40 \pm 0.16 \mathrm{~B}$ & $4.71 \pm 0.58 \mathrm{~A}$ & $5.98 \pm 0.70 \mathrm{a}$ & $3.68 \pm 0.41 \mathrm{~b}$ & $2.50 \pm 0.53 c$ & $<0.0001$ & $<0.0001$ \\
\hline Total polyphenols (mg/100 g DW) & $835.33 \pm 0.07 \mathrm{~B}$ & $1067.16 \pm 0.05 \mathrm{~A}$ & $836.18 \pm 0.04 \mathrm{c}$ & $931.41 \pm 0.02 b$ & $1086.15 \pm 0.07 \mathrm{a}$ & $<0.0001$ & $<0.0001$ \\
\hline Total phenolic acids & $309.53 \pm 9.67 \mathrm{~B}$ & $416.00 \pm 4.48 \mathrm{~A}$ & $244.20 \pm 2.14 \mathrm{c}$ & $347.27 \pm 4.01 \mathrm{~b}$ & $496.82 \pm 6.69 \mathrm{a}$ & $<0.0001$ & $<0.0001$ \\
\hline Gallic acid & $0.73 \pm 0.05 \mathrm{~B}$ & $0.94 \pm 0.23 \mathrm{~A}$ & $0.79 \pm 0.13 \mathrm{~b}$ & $0.94 \pm 0.03 \mathrm{a}$ & $0.77 \pm 0.02 \mathrm{~b}$ & 0.0031 & 0.0480 \\
\hline Chlorogenic acid & $39.56 \pm 1.43 \mathrm{~A}$ & $41.02 \pm 0.56 \mathrm{~A}$ & $38.03 \pm 0.56 \mathrm{~b}$ & $52.16 \pm 0.09 \mathrm{a}$ & $30.67 \pm 0.65 b$ & N.S. & 0.0002 \\
\hline Caffeic acid & $1.13 \pm 0.14 \mathrm{~B}$ & $1.33 \pm 0.44 \mathrm{~A}$ & $1.65 \pm 0.09 \mathrm{a}$ & $1.13 \pm 0.04 \mathrm{ab}$ & $0.92 \pm 0.36 \mathrm{~b}$ & 0.0001 & $<0.0001$ \\
\hline$p$-Coumaric acid & $8.14 \pm 9.97 \mathrm{~A}$ & $5.65 \pm 80.20 \mathrm{~B}$ & $8.84 \pm 9.88 \mathrm{a}$ & $3.54 \pm 2.45 \mathrm{~b}$ & $8.31 \pm 49.89 \mathrm{a}$ & $<0.0001$ & $<0.0001$ \\
\hline Ferulic acid & $1.49 \pm 0.19 \mathrm{~A}$ & $1.59 \pm 0.70 \mathrm{~A}$ & $1.63 \pm 0.71 \mathrm{a}$ & $1.13 \pm 0.19 \mathrm{a}$ & $1.85 \pm 0.03 \mathrm{a}$ & N.S. & N.S. \\
\hline Ellagic acid & $276.94 \pm 0.81 \mathrm{~B}$ & $365.66 \pm 3.99 \mathrm{~A}$ & $211.36 \pm 0.52 \mathrm{~b}$ & $288.37 \pm 0.73 b$ & $464.18 \pm 3.32 \mathrm{a}$ & $<0.0001$ & $<0.0001$ \\
\hline Total flavonoids (mg/100 g DW) & $525.80 \pm 0.09 \mathrm{~B}$ & $651.16 \pm 0.12 \mathrm{~A}$ & $591.98 \pm 0.10 \mathrm{a}$ & $584.14 \pm 0.03 \mathrm{a}$ & $589.32 \pm 0.09 \mathrm{a}$ & $<0.0001$ & N.S. \\
\hline Total flavonols (mg/100 g DW) & $23.84 \pm 1.32 \mathrm{~B}$ & $32.50 \pm 5.32 \mathrm{~A}$ & $25.45 \pm 0.27 \mathrm{ab}$ & $23.88 \pm 0.77 b$ & $35.17 \pm 4.51 \mathrm{a}$ & $<0.0001$ & $<0.0001$ \\
\hline Quercetin-3-O-rutinoside & $6.92 \pm 0.09 \mathrm{~B}$ & $14.10 \pm 0.23 \mathrm{~A}$ & $9.10 \pm 0.03 \mathrm{~b}$ & $6.58 \pm 0.16 \mathrm{c}$ & $15.85 \pm 0.10 \mathrm{a}$ & $<0.0001$ & $<0.0001$ \\
\hline Myricetin & $2.77 \pm 0.14 \mathrm{~A}$ & $2.51 \pm 0.40 \mathrm{~B}$ & $2.60 \pm 0.11 \mathrm{a}$ & $2.71 \pm 0.09 \mathrm{a}$ & $2.60 \pm 0.30 \mathrm{a}$ & 0.0330 & N.S. \\
\hline Luteolin & $1.07 \pm 0.50 \mathrm{~B}$ & $1.59 \pm 0.95 \mathrm{~A}$ & $0.90 \pm 0.33 \mathrm{~b}$ & $1.41 \pm 0.16 \mathrm{ab}$ & $1.68 \pm 0.83 \mathrm{a}$ & $<0.0001$ & $<0.0001$ \\
\hline Quercetin-3-O-glucoside & $1.85 \pm 0.11 \mathrm{~B}$ & $2.09 \pm 0.90 \mathrm{~A}$ & $1.72 \pm 0.57 b$ & $1.76 \pm 0.39 \mathrm{~b}$ & $2.44 \pm 0.56 \mathrm{a}$ & 0.0078 & N.S. \\
\hline Kaempferol & $11.22 \pm 2.51 \mathrm{~B}$ & $12.21 \pm 2.05 \mathrm{~A}$ & $11.14 \pm 2.32 b$ & $11.41 \pm 1.22 \mathrm{~b}$ & $12.60 \pm 1.13 \mathrm{a}$ & 0.0025 & 0.0014 \\
\hline Total anthocyanins (mg/100 g DW) & $501.96 \pm 2.25 \mathrm{~B}$ & $618.66 \pm 2.67 \mathrm{~A}$ & $566.53 \pm 3.35 \mathrm{a}$ & $560.26 \pm 2.46 a$ & $554.15 \pm 3.06 \mathrm{a}$ & $<0.0001$ & N.S. \\
\hline Cyanidin-3-O-glucoside & $260.54 \pm 7.51 \mathrm{~B}$ & $354.68 \pm 4.05 \mathrm{~A}$ & $311.39 \pm 12.32 \mathrm{a}$ & $307.01 \pm 11.22 \mathrm{a}$ & $304.43 \pm 18.13 \mathrm{a}$ & $<0.0001$ & N.S. \\
\hline Pelargonidin-3-O-glucoside & $55.24 \pm 2.25 \mathrm{~B}$ & $72.24 \pm 2.67 \mathrm{~A}$ & $65.82 \pm 3.35 \mathrm{a}$ & $62.79 \pm 2.46 \mathrm{a}$ & $62.61 \pm 3.06 \mathrm{a}$ & 0.0003 & N.S. \\
\hline Delphinidinn-3-O-glucoside & $186.18 \pm 6.23 \mathrm{~A}$ & $191.74 \pm 4.17 \mathrm{~A}$ & $189.32 \pm 3.96 \mathrm{a}$ & $190.46 \pm 1.11 \mathrm{a}$ & $187.10 \pm 5.16 \mathrm{a}$ & N.S. & N.S. \\
\hline
\end{tabular}

${ }^{1}$ Data are presented as the mean \pm SE with ANOVA $p$-value; ${ }^{2}$ Means in rows followed by the same letter $(\mathrm{A}, \mathrm{B}, \mathrm{a}-\mathrm{c})$ are not significantly different at the $5 \%$ level of probability $(p<0.05)$;

N.S. not significant; (n) number of samples (field replications). $n=36$ for system, $n=12$ of cultivar. 
Table 4. The content of Bet v1 as ELISA results ng/g DW.

\begin{tabular}{cccccc}
\hline \multicolumn{3}{c}{ Organic Raspberry 2013 } & \multicolumn{3}{c}{ Conventional Raspberry 2013 } \\
\hline ‘Laszka' cv. & 'Glen Ample' cv. & 'Polka' cv. & 'Laszka' cv. & 'Glen Ample' cv. & 'Polka' cv. \\
\hline 920.20 & 769.20 & 667.10 & 918.50 & 934.50 & 742.70 \\
\hline 890.30 & 779.40 & 687.11 & 899.70 & 935.60 & 752.30 \\
\hline 944.10 & 759.90 & 660.30 & 934.50 & 924.50 & 739.90 \\
\hline \multicolumn{3}{c}{ Organic Raspberry 2014 } & \multicolumn{2}{c}{ Conventional Raspberry 2014 } \\
\hline ‘Laszka' cv. & 'Glen Ample' cv. & 'Polka' cv. & 'Laszka' cv. & 'Glen Ample' cv. & 'Polka' cv. \\
\hline 783.90 & 895.90 & 756.00 & 830.10 & 813.70 & 827.70 \\
\hline 799.20 & 945.60 & 788.90 & 823.40 & 825.60 & 839.90 \\
\hline 777.80 & 866.70 & 765.80 & 812.12 & 822.90 & 811.00 \\
\hline
\end{tabular}

Table 5. The content of profilins as ELISA results $\mu \mathrm{g} / \mathrm{g}$ DW.

\begin{tabular}{cccccc}
\hline & \multicolumn{3}{c}{ Organic Raspberry 2013 } & \multicolumn{3}{c}{ Conventional Raspberry 2013 } \\
\hline ‘Laszka' cv. & 'Glen Ample' cv. & 'Polka' cv. & 'Laszka' cv. & 'Glen Ample' cv. & 'Polka' cv. \\
\hline 6.263 & 3.767 & 3.56 & 2.483 & 1.214 & 6.712 \\
\hline 6.759 & 2.682 & 3.62 & 2.864 & 1.790 & 5.922 \\
\hline 6.099 & 3.434 & 3.46 & 2.323 & 1.777 & 6.331 \\
\hline \multicolumn{3}{c}{ Organic Raspberry 2014 } & \multicolumn{3}{c}{ Conventional Raspberry 2014 } \\
\hline 'Laszka' cv. & 'Glen Ample' cv. & 'Polka' cv. & 'Laszka' cv. & 'Glen Ample' cv. & 'Polka' cv. \\
\hline 3.740 & 2.284 & 4.741 & 8.139 & 5.104 & 2.54 \\
\hline 3.705 & 2.203 & 4.153 & 8.981 & 4.927 & 2.39 \\
\hline 3.323 & 2.345 & 4.099 & 8.009 & 5.244 & 2.57 \\
\hline
\end{tabular}

The PCA results showed that the overall degree of variability explained by PC1 and PC2 was 94.54\% in 2013 and 80.24\% in 2013 and 2014, respectively (Figures 2 and 3). This was confirmed by a strong link between the measured chemical compounds and the allergenic proteins identified in the raspberries. In both years of the experiment, the 'Polka' and 'Laszka' cultivars were positively correlated with organic raspberries. As shown in the graph, for both years of the experiment, the organic and conventional raspberries were grown in completely separate areas. This arrangement suggests a complete chemical dissimilarity between the examined fruits. 


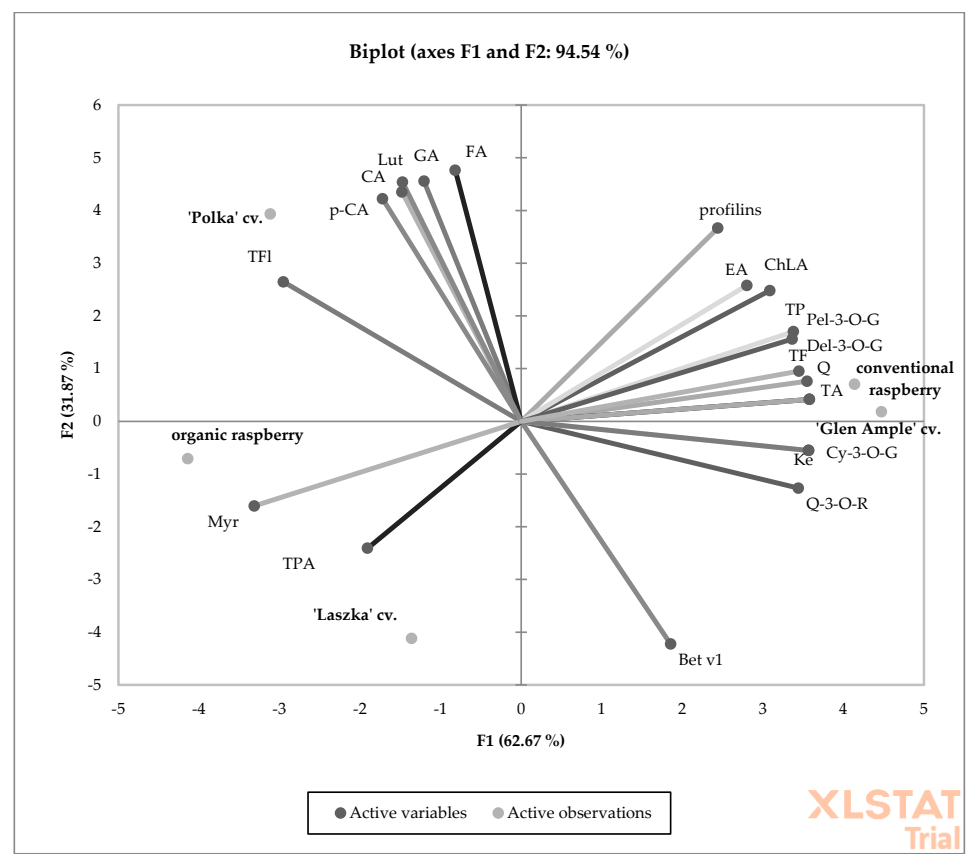

Figure 2. PCA analysis showing the relationship between the chemical composition and allergy potential of organic and conventional raspberry in 2013. (Bet v1) Bet v1; (profilins) profilins; (TP) total polyphenols; (TPA) total phenolic acids; (GA) gallic acid; (ChLA) chlorogenic acid; (CA) caffeic acid; ( $p$-CA) p-coumaric acid; (FA) ferulic acid; (EA) ellagic acid; (TF) total flavonoids; (TFl) total flavonols; (Q-3-O-R) quercetin-3-O-rutinoside; (Myr) myricetin; (Lut) luteolin; (Q) quercetin; (Ke) kaempferol; (TA) total anthocyanins; (Cy-3-O-G) cyanidin-3-O-glucoside; (Pel-3-O-G) pelargonidoin-3-O-glucoside; (Del-3-O-G)delphinidin-3-O-glucoside.

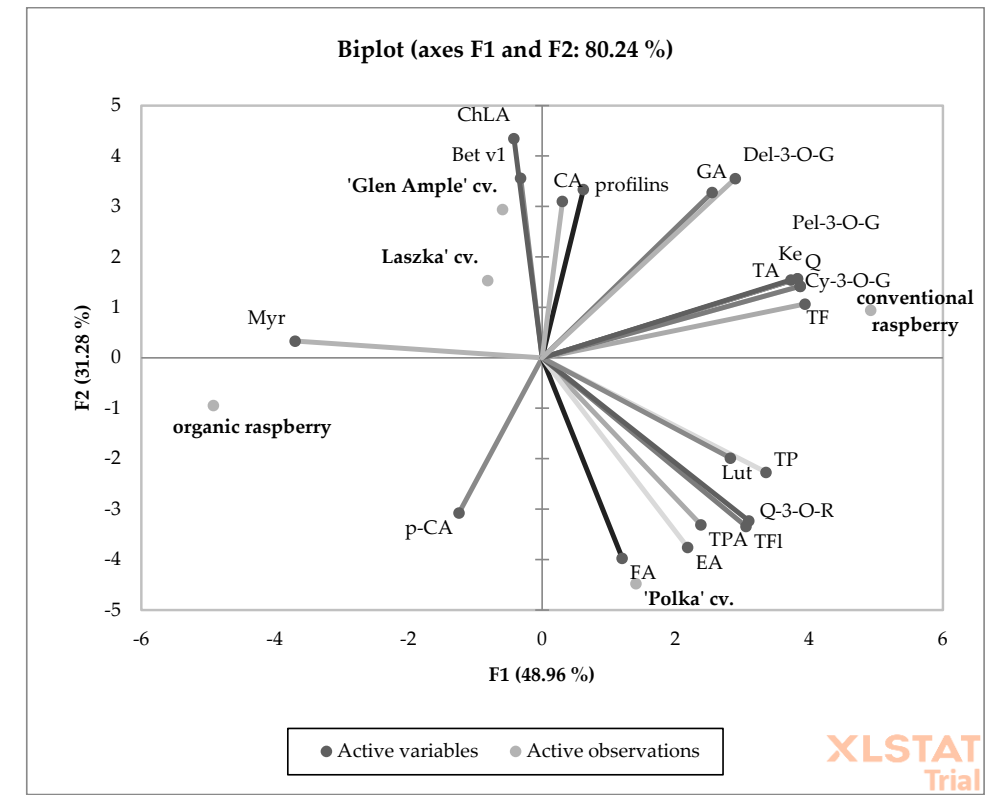

Figure 3. PCA analysis showing the relationship between the chemical composition and allergy potential of organic and conventional raspberry in 2014. (Bet v1) Bet v1; (profilins) profilins; (TP) total polyphenols; (TPA) total phenolic acids; (GA) gallic acid; (ChLA) chlorogenic acid; (CA) caffeic acid; ( $p$-CA) p-coumaric acid; (FA) ferulic acid; (EA) ellagic acid; (TF) total flavonoids; (TFl) total flavonols; (Q-3-O-R) quercetin-3-O-rutinoside; (Myr) myricetin; (Lut) luteolin; (Q) quercetin; (Ke) kaempferol; (TA) total anthocyanins; (Cy-3-O-G) cyanidin-3-O-glucoside; (Pel-3-O-G) pelargonidoin-3-O-glucoside; (Del-3-O-G)delphinidin-3-O-glucoside. 


\section{Discussion}

Raspberries are among the most tasty and healthiest fruits in the world. Consumers like them and consume them in different forms, as both fresh and processed fruit. From a health point of view, raspberry fruits contain many bioactive compounds, such as polyphenols (especially flavonols and anthocyanins) and vitamin C [20-23]. According to strict farming rules, organic farming is one of the best alternatives for high-quality and safe fruit production [24]. Many experiments have shown that organic fruits contain more bioactive compounds than conventionally raised fruits [25-27], but some experiments have shown the opposite results $[28,29]$. In the present study, we showed that organic raspberries contained fewer total polyphenols and flavonoids, especially purple pigments (anthocyanins), than conventionally raised raspberries (Tables 2 and 3). This finding is due to the use of dry matter content in fruits. Many results of chemical composition and polyphenolic compounds in raspberry fruits are presented as the fresh weight $[30,31]$. In such a situation, the higher dry matter and polyphenol content in organic fruits can lead to the opposite result-a lower concentration of phenolic compounds after the re-calculation of the results and presenting them as the dry matter content [26,32]. When a raspberry is consumed fresh or in desserts, the content of bioactive compounds in the fresh matter is the most important information for a consumer. On the other hand, we were looking for a link between the content of biologically active compounds and their allergenic potential. In this situation, we decided it was more informative to present the results calculated on a dry matter basis. Conventional raspberries contained more phenolic acids than organic raspberries. Similar results were presented by others [26,27]. The higher content of phenolic acids in conventional raspberry fruits may be an effect of abiotic salinity stress. It worth noting that in organic farming, only animal manure is used for fertilization. In conventional systems, mineral fertilizers are used. According to the data presented in Table 1, soil from the conventional farms had a higher salt concentration, which was reflected by the higher EC status. This could be the result of the effect of salinity stress inducing a higher phenolic acid production by the plants [33]. When plants are exposed to a higher salt concentration, their tissues produce more phenolic acids. These compounds are produced in the roots and then transported to the rest of the plant, including the fruits [34]. In both years of the experiment, we observed the lowest level of total phenolic acids in the 'Laszka' cv cultivar. The variation in phenolic acid contents between cultivars is based on genetic factors. In the experiment presented by Pavlović et al. [35] among four raspberry cultivars, 'Tulameen' cv. was characterized by the lowest level of phenolic acids, with a value of $604.6 \mathrm{mg} / 100 \mathrm{~g}$ DW, and 'Willamette' had the highest level (1021.4 mg/100 g DW). In raspberry fruits, flavonoids play an important role. Anthocyanins belong to the flavonoids group. They are synthesized and stored in raspberry fruits. Among the different plant secondary metabolites, flavonoids are important compounds. Plants produce flavonoids as a reaction against intensive sun radiation to protect their tissues against UV radiation [36]. We observed a stable reaction of raspberry fruits against sun radiation among the examined cultivars. In both years of the experiment, 'Polka' cv. contained significantly higher levels of total flavonols in its fruits (Tables 2 and 3). A similar situation was observed in another experiment. Two different raspberry cultivars produced significantly different levels of total flavonols, 'Amira' cv. at $19.52 \mathrm{mg} / 100 \mathrm{~g}$ DW while 'Polka' cv. was $31.06 \mathrm{mg} / 100 \mathrm{~g}$ DW [22]. This effect could be explained by the genetic differentiation of raspberry cultivars. Anthocyanin synthesis in raspberry fruits depends on many intrinsic and external factors. There are genes that regulate anthocyanin synthesis originally at the transcriptional level. In addition, since these pigments provide plants with UV tolerance, their production is regulated by distinct special genes that are strongly regulated by sunlight exposure. A higher dose of light available for raspberry plants results in a higher anthocyanin concentration in the fruits. It should be noted that the longer exposure of raspberry plants to sunlight and a higher total number of sunny hours per day result in a higher concentration of the total anthocyanins in the raspberry fruits [37]. In the present experiment, we noted that phenomenon in action. According to the data presented in Figure 1, although the experimental farms were located very close to each other, the conventional area was in a higher sun zone than the organic area. In May and June, the conventional raspberry farm was exposed to higher levels of sunlight during the fruit 
set and development period than the organic farm. That is why in both years of the experiment, we found that the conventional fruits had higher amounts of total anthocyanins as well as individual purple pigments (cyanidin-3-O-glucoside and pelargonidin-3-O-glucoside) than the organic fruits (Tables 2 and 3). We found a strong linear correlation between the total anthocyanins and Bet v1 content in 2014 as well as the profilins content in both experimental years for conventional raspberries (Table 6). Strawberry allergen has an impact on the pathway for the synthesis of enzymes responsible for the synthesis of anthocyanins. Therefore, a lower allergen content directly affects a lower anthocyanin content. White strawberries-colorless strawberry mutants known to be tolerated by individuals affected by allergies-were found to be virtually free from the strawberry allergen [38]. It seems that the white fruits were more easily tolerated by volunteers suffering from fruit allergies than normal fruits [39]. Moreover, the level of Bet v1 in white strawberry mutants was almost zero. This could mean that dark-colored strawberries increase patients' allergic reactions. Because raspberries and strawberries are closely related (the same family Rosaceae), we could expect similar results with raspberries. In our experiment, the level of Bet v1 was higher in the conventional raspberries (Table 2). Among the patients suffering from specific Rosaceae fruit allergies, it is not possible to evaluate which fruit and pollen allergies are typically associated from the available studies. In one of these studies, carried out in Spain, profilin-sensitized patients allergic to Rosaceae fruits and pollens were sensitized to both a higher number of fruits and a wider variety of fruits, including fruits outside the Rosaceae family [12]. In Europe, Rosaceae fruit allergies and LTP sensitization are almost absent. The major fruit allergy pattern characteristic of this area is an association between birch pollen allergy and Rosaceae fruit allergy, with PR-10 as the most frequent cross- reacting allergen [40]. In addition, we should remember that conventionally raised raspberry fruits may contain many harmful chemicals and compounds. Among the synthetic chemicals used in conventional agriculture, pesticides are the most serious. These chemicals can have carcinogenic, neurodegenerative and allergic effects [41]. Crops produced under the strict rules of organic farming are safer and contain fewer toxins as well as fewer allergenic substances than products from conventional farming. The present results are in accordance with the beliefs of consumers, who feel that organic fruits are safer and of higher quality. It is worth pointing out that in the case of raspberries, we found lower levels of dangerous Bet v1 and profilins in the organic fruits (Tables 2 and 3). However, the obtained results are opposite of findings presented previously for different organic crops. Organic apricots were characterized by higher Bet v1 and profilin contents [19]. Organic tomato contained higher concentrations of profilins but not Bet v1 [42]. There is also some evidence that fully ripened tomato fruits cause a stronger allergic reaction than orange red fruits (not fully ripened) [43]. In tomatoes, it seems that the allergenic potential is connected with the pigment carotenoids. Of course, in the examined raspberries, we found a link between pigments and allergy potential, but anthocyanins and carotenoids belong to completely different chemical groups. On the other hand, it could be pointed out that allergic reactions may involve exposure to different chemical agents. In the case of organic tomatoes, it was not only food intolerance but also a skin test that confirmed the higher level of their allergenic potential. Using genetic and breeding approaches, it is possible to find numerous Rubus genotypes for the Rub i 1 and Rub i 3 proteins. In could be that some wild varieties or plants growing in less sunny areas (the north Europe countries) seem to be free of allergens. Thus, farming practices can take advantage of the biodiversity of Rubus to select for hypoallergenic raspberry lines [44]. On the other hand, based on the obtained results, we may take advantage of the fact that organic raspberries contain a lower level of Bet v1. 
Table 6. The value of $\mathrm{R}^{2}$ coefficient for Pearson regression between phenolics compounds and allergen analogs for organic and conventional raspberries.

\begin{tabular}{ccccc}
\hline \multirow{2}{*}{ Type of Regression } & \multicolumn{2}{c}{2013} & \multicolumn{2}{c}{2014} \\
\cline { 2 - 5 } & $\begin{array}{c}\text { Organic } \\
\text { Raspberry }\end{array}$ & $\begin{array}{c}\text { Conventional } \\
\text { Raspberry }\end{array}$ & $\begin{array}{c}\text { Organic } \\
\text { Raspberry }\end{array}$ & $\begin{array}{c}\text { Conventional } \\
\text { Raspberry }\end{array}$ \\
\hline polyphenols/Bet v1 & +0.8349 & +0.7017 & +0.6213 & +0.7705 \\
\hline$p$-value & 0.006 & 0.0048 & 0.0116 & 0.0019 \\
\hline polyphenols/profilins & +0.7934 & +0.933 & +0.8958 & +0.8235 \\
\hline$p$-value & 0.0130 & $<0.0001$ & 0.0001 & 0.0007 \\
\hline anthocyanins/Bet v1 & +0.6995 & +0.5631 & +0.8445 & +0.9065 \\
\hline$p$-value & 0.0050 & 0.019 & 0.0005 & $<0.0001$ \\
\hline anthocyanins/profilins & +0.6781 & +0.9852 & +0.7650 & +0.8235 \\
\hline$p$-value & 0.0064 & $<0.0001$ & $<0.0001$ & 0.0002 \\
\hline
\end{tabular}

\section{Conclusions}

Considering the obtained results, organic raspberry could be more useful for those consumers suffering from slight allergy symptoms. The higher level of anthocyanins could be used as an indicator for the concentration of allergy proteins.

Author Contributions: Conceptualization, E.H., J.L.; data curation, E.H., M.A; T.N.; formal analysis E.H., M.A., T.N.; funding acquisition, J.L., E.H.; methodology, E.H., J.L.; project administration E.H., J.L.; resources T.N., M.A.; supervision E.H., J.L.; validation E.H., visualization A.P., E.H.; writing original draft A.P., E.H., All authors have read and agreed to the published version of the manuscript.

Funding: This research received no external funding.

Acknowledgments: This paper has been published with the support of the Polish Ministry of Higher Education within the foundation of the Institute of Human Nutrition Sciences, Warsaw University of Life Sciences (WULS), for scientific research.

Conflicts of Interest: The authors declare no conflict of interest.

\section{References}

1. Braidy, N.; Behzad, S.; Habtemariam, S.; Ahmed, T.; Daglia, M.; Mohammad, N.S.; Sobarzo-Sanchez, E.; Fazel, N.S. Neuroprotective effects of citrus fruit-derived flavonoids, nobiletin and tangeretin in Alzheimer's and Parkinson's disease. CNS Neurol. Disord. Dr. 2017, 16, 387-397. [CrossRef] [PubMed]

2. Wang, Y.; Fang, Y.-C.; Gao, Z.-H.; Zhang, C.; Xie, S.-Y. Higher intake of fruits, vegetables or their fiber reduces the risk of type 2 diabetes: A meta-analysis. J. Diabetes Investig. 2016, 7, 56-69. [CrossRef]

3. Aune, D.; Giovannucci, E.; Boffetta, P.; Fadnes, L.T.; Keum, N.N.; Norat, T.; Greenwood, D.C.; Riboli, E.; Vatten, L.J.; Tonstad, S. Fruit and vegetable intake and the risk of cardiovascular disease, total cancer and all-cause mortality-A systematic review and dose response meta-analysis of prospective studies. Int. J. Epidemiol. 2014, 46, 1029-1056.

4. Ellwood, L.; Gizemnur, T.; Zuhal, B.; Ritin, F. Effectiveness of flavonoid rich fruits for hypertension in adults a systematic review protocol. JBI Database Syst. Rev. Implement. Rep. 2018, 16, 2103-2108. [CrossRef] [PubMed]

5. Villani, A.; Wright, H.; Slater, G.; Buckley, J. A randomized controlled intervention study investigating the efficacy of carotenoid-rich fruits and vegetables and extra-virgin olive oil on attenuating sarcopenic symptomology in overweight and obese older adults during energy intake restriction: Protocol paper. BMC Geriatrics 2018, 18, 1-10.

6. Council Regulation (EC) No 834/2007 of 28 June 2007 on Organic Production and Labelling of Organic Products and Repealing Regulation (EEC) No 2092/91. Available online: https://eur-lex.europa.eu/legalcontent/EN/TXT/?uri=celex\%3A32007R0834 (accessed on 20 February 2020). 
7. Yang, L.; Wen, K.-S.; Ruan, X.; Zhao, Y.-X.; Wei, F.; Wang, Q. Response of plant secondary metabolites to environmental factors. Molecues 2018, 23, 762. [CrossRef]

8. Kazimierczak, R.; Hallmann, E.; Kowalska, K.; Rembiałkowska, E. Biocompounds content in organic and conventional raspberry fruits. Acta Fytotechn. Zootechn. 2015, 18, 40-42. [CrossRef]

9. Dosanjh, A. Raspberry allergen and Rosaceae family member allergens: Clinical and cellular responses. J. Interferon Cytokine Res. 2019, 39, 273-282. [CrossRef]

10. Shahali, Y.; Dadar, M. Plant food allergy: Influence of chemicals on plant allergens. Food Chem. Toxicol. 2019, 115, 365-374. [CrossRef]

11. Cariñanos, P.; Delgado-Capel, M.; Maradiaga-Marína, F.; Beníteza, G. Considerations on the allergy-risks related to the consumption of fruits from urban trees in Mediterranean cities. Urban For. Urban Green. 2019, 45, doi. [CrossRef]

12. Andersen, M.B.S.; Hall, S.; Dragsted, L.O. Identification of European allergy patterns to the allergen families pr-10, LTP, and profilin from Rosaceae fruits. Clin. Rev. Allergy Immunol. 2011, 41, 4-19. [CrossRef] [PubMed]

13. Žiarovská, J.; Zeleňáková, L. Application of Genomic Data for PCR Screening of BET v 1 Conserved Sequence in Clinically Relevant Plant Species. In Systems Biology; InTech Open: Nitra, Slovak Republic, 2018; pp. 1-19.

14. Muñoz, C.; Hoffmann, T.; Escobar, N.M.; Ludemann, F.; Botella, M.A.; Valpuesta, V.; Schwab, W. The strawberry fruit Fra a allergen functions in flavonoid biosynthesis. Mol. Plant. 2010, 3, 113-124. [CrossRef] [PubMed]

15. Kinaciyan, T.; Nagl, B.; Faustmann, S.; Frommlet, F.; Kopp, S.; Wolkersdorfer, M.; Wöhrl, S.; Bastl, K.; Huber, H.; Berger, U.; et al. Efficacy and safety of 4 months of sublingual immunotherapy with recombinant Mal d 1 and Bet v 1 in patients with birch pollen-related apple allergy. J. Allergy Clin. Immunol. 2017, 141, 1002-1008. [CrossRef] [PubMed]

16. Kleine-Tebbe, J.; Ollert, M.; Radauer, C.; Jakob, T. Introduction to Molecular Allergology: Protein families, databases, and potential benefits. In Molecular Allergy Diagnosis; Springer: Berlin/Heidelberg, Germany, 2010; pp. 21-42.

17. Mothes-Luksch, N.; Raith, M.; Stingl, G.; Focke-Tejkl, M.; Razzazi-Fazeli, E.; Zieglmayer, R.; Wöhrl, S.; Swoboda, I. Pru p 3, a marker allergen for lipid transfer protein sensitization also in Central Europe. Allergy 2017, 72, 1415-1418. [CrossRef] [PubMed]

18. Chang, C.; Leung, P.S.C.; Todi, S.; Zadoorian, L. Definition of Allergens: Inhalants, Food and Insects Allergens. In Allergy and Asthma; Springer Nature: Cham, Switzerland, 2019; pp. 77-81.

19. Hallmann, E.; Rozpara, E.; Słowianek, M.; Leszczyńska, J. The effect of organic and conventional farm management on the allergenic potency and bioactive compounds status of apricots (Prunus armeniaca $\mathrm{L}$ ). Food Chem. 2019, 279, 171-178. [CrossRef] [PubMed]

20. Dóka, O.; Ficzek, G.; Bicanic, D.; Spruijt, R.; Luterotti, S.; Tóth, M.; Buijnsters, J.G.; Vegvari, G. Direct phytochemical techniques for rapid quantification of total anthocyanins content in sour cherry cultivars. Talanta 2011, 84, 341-346. [CrossRef]

21. Borges, G.; Degeneve, A.; Mullen, W.; Crozier, A. Identification of flavonoid and phenolic antioxidants in black currants, blueberries, raspberries, red currants, and cranberries. J. Agric. Food Chem. 2010, 58, 3901-3909. [CrossRef]

22. Zorenc, Z.; Veberic, R.; Koron, D.; Mikulic-Petkovsek, M. Impact of raspberry (Rubus idaeus L.) primocane tipping on fruit yield and quality. Not. Bot. Horti. Agrobo. 2017, 45, 417-424. [CrossRef]

23. Kim, M.K.; Kim, M.-Y.; Lee, K.-G. Categorization of fruits according to their content of polyphenols and vitamin C, antiradical activity, and quality parameters. J. Food Process. Pres. 2018, 42, 1-6. [CrossRef]

24. Fernandes, F.C.; Domingues, V.F.; de Freitas, V.; Delerue-Matos, C.; Mateus, N. Strawberries from integrated pest management and organic farming: Phenolic composition and antioxidant properties. Food Chem. 2012, 134, 1926-1931. [CrossRef]

25. Asami, D.K.; Hong, Y.J.; Barrett, D.M.; Mitchell, A.E. Comparison of the total phenolic and ascorbic acid content of freeze-dried and air-dried marionberry, strawberry, and corn grown using conventional, organic, and sustainable agricultural practices. J. Agric. Food Chem. 2003, 51, 1237-1241. [CrossRef] [PubMed]

26. Crecente-Campo, J.; Nunes-Damaceno, M.; Romero-Rodríguez, M.A.; Vázquez-Odériz, M.L. Color, anthocyanin pigment, ascorbic acid and total phenolic compound determination in organic versus conventional strawberries (Fragaria x ananassa Duch, cv Selva). J. Food Comp. Anal. 2012, 28, 23-30. [CrossRef] 
27. Kazimierczak, R.; Hallmann, E.; Babbała, J.; Rembiałkowska, E. The Content of Antioxidant Compounds in the Fruit of Selected Berry Species from Organic and Conventional Production Systems. In Selected Problems of Nutraceutical and Functional Food; MedPharm Polska: Wroclaw, Poland, 2011; pp. 21-27.

28. Skupień, K.; Ochniam, I.; Grajkowski, J.; Krzywy-Gawrońska, E. Nutrients, antioxidants, and antioxidant activity of organically and conventionally grown raspberries. J. Appl. Bot. Food Qual. 2011, 84, 85-89.

29. Tassoni, A.; Tango, N.; Ferri, M. Comparison of biogenic amine and polyphenol profiles of grape berries and wines obtained following conventional, organic and biodynamic agricultural and oenological practices. Food Chem. 2013, 139, 405-413. [CrossRef]

30. Ornelas-Paz, J.J.; Yahia, E.M.; Ramírez-Bustamante, N.; Pérez-Martínez, J.D.; Escalante-Minakata, M.P.; Ibarra-Junquera, V.; Acosta-Muñiz, C.; Guerrero-Prieto, V.; Ochoa-Reyes, E. Physical attributes and chemical composition of organic strawberry fruit (Fragaria $x$ ananassa Duch, Cv. Albion) at six stages of ripening. Food Chem. 2013, 138, 372-381. [CrossRef]

31. De Ancos, B.; González, E.M.; Cano, M.P. Ellagic acid, vitamin C, and total phenolic contents and radical scavenging capacity affected by freezing and frozen storage in raspberry fruit. J. Agric. Food Chem. 2000, 48, 4565-4570. [CrossRef]

32. Hallmann, E.; Piotrowska, A.; Świąder, K. The effect of organic practices on the bioactive compounds content in strawberry fruits. J. Res. Appl. Agric. Eng. 2016, 61, 176-179.

33. Waśkiewicz, A.; Muzolf-Panek, M.; Goliński, P. Phenolic Content Changes in Plants under Salt Stress. In Ecophysiology and Responses of Plants under Salt Stress; Springer: London, UK, 2013; pp. 293-299.

34. Cardeñosa, V.; Medrano, E.; Lorenzo, P.; Sánchez-Guerrero, M.C.; Cuevas, F.; Pradasa, I.; Moreno-Rojasa, J.M. Effects of salinity and nitrogen supply on the quality and health-related compounds of strawberry fruits (Fragaria $\times$ ananassa cv. Primoris). J. Sci. Food Agric. 2015, 95, 2924-2930. [CrossRef]

35. Pavlović, A.V.; Papetti, A.; Zagorać, D.Č.D.; Gašić, U.M.; Mišić, D.M.; Tešić, Z.J.; Natić, M.M. Phenolics composition of leaf extracts of raspberry and blackberry cultivars grown in Serbia. Ind. Crop Prod. 2016, 87, 304-314. [CrossRef]

36. Xie, Z.; Charles, M.T.; Fan, J.; Charlebois, D.; Khanizadeh, S.; Rolland, D.; Roussel, D.; Deschênesa, M.; Dubéa, C. Effects of preharvest ultraviolet-C irradiation on fruit phytochemical profiles and antioxidant capacity in three strawberry (Fragaria $\times$ ananassa Duch.) cultivars. J. Sci. Food Agric. 2015, 95, 2996-3002. [CrossRef]

37. Josuttis, M.; Dietrich, H.; Treutter, D.; Will, F.; Linnemannstöns, L.; Krüger, E. Solar UVB response of bioactives in strawberry (Fragaria $\times$ ananassa Duch. L.): A comparison of protected and open-field cultivation. J. Agri. Food Chem. 2010, 58, 12692-12702. [CrossRef] [PubMed]

38. Hjernø, K.; Alm, R.; Canbäck, B.; Matthiesen, R.; Trajkovski, K.; Björk, L.; Roepstorff, P.; Emanuelsson, C. Down-regulation of the strawberry Bet $\mathrm{v} 1$ homologous in the concert with the flavonoids biosynthesis pathway in colorless strawberry mutant. Proteomics 2006, 6, 1574-1587. [CrossRef] [PubMed]

39. Franz-Oberdorf, K.; Eberlein, B.; Edelmann, K.; Bleicher, P.; Kurze, E.; Helm, D.; Ring, J.; Schwab, W. White-fruited strawberry genotypes are not per se hypoallergenic. Food Res. Int. 2017, 100, 748-756. [CrossRef] [PubMed]

40. Zuidmeer, L.; Goldhahn, K.; Rona, R.J.; Gislason, D.; Madsen, C.; Summers, C.; Sodergren, E.; Dahlstrom, J.; Lindner, T.; Sigurdardottir, S.T.; et al. The prevalence of plant food allergies: A systematic review. J. Allergy Clin. Immunol. 2008, 121, 1210-1218. [CrossRef]

41. Blair, A.; Ritz, B.; Wesseling, C.; Freeman, L.B. Pesticides and human health. Ann. Occup. Environ. Med. 2010, 1, 1-3. [CrossRef]

42. Słowianek, M.; Skorupa, M.; Hallmann, E.; Rembiałkowska, E.; Leszczyńska, J. Allergenicity of tomatoes cultivated in organic and conventional systems. Plant Food Hum. Nutrit. 2016, 71, 35-41. [CrossRef]

43. Kitagawa, M.; Moriyama, T.; Ito, H.; Ozasa, S.; Adachi, A.; Yasuda, J.; Ookura, T.; Inakuma, T.; Kasumi, T.; Ishiguro, Y.; et al. Reduction of allergenic proteins by the effect of the ripening inhibitor (rin) mutant gene in an F1 hybrid of the rin mutant tomato. Biosci. Biotechnol. Biochem. 2006, 70, 1227-1233. [CrossRef]

44. Franz, K.; Eberlein, B.; Hücherig, S.; Edelmann, K.; Besbes, F.; Ring, J.; Darsow, U.; Schwab, W. Breeding of hypoallergenic strawberry fruit. J. Berry Res. 2016, 3, 197-201. [CrossRef]

(C) 2020 by the authors. Licensee MDPI, Basel, Switzerland. This article is an open access article distributed under the terms and conditions of the Creative Commons Attribution (CC BY) license (http://creativecommons.org/licenses/by/4.0/). 